\title{
Nanotechnology to Beat Generic and Patent Cliff Ophthalmic Project
}

\author{
Mewa Singh* \\ Meda Biotech LLC, USA
}

Submission: July 13, 2017; Published: August 02, 2017

*Corresponding author: Mewa Singh, CEO, Meda Biotech LLC, USA; Tel: 609-902-728; Email: mynanoview@gmail.com; info@nanomeda.com

\section{Rational and Summary}

There were few questions to be answered before start our company to invest our limited resources;

1. Is there a need of new molecule or new technology to have a better treatment?

2. What is better mean: less expensive with same efficacy? Less expensive with more efficacy? Or more expensive with same efficacy?

3. Why the formulations for best molecules are still compromised in delivery system?

Our decision was too bring a better technology to improve the compromised delivery system. Our limited resources discovered a new technology to make majority of tough molecules becomes water soluble and named this innovation as HYBRID-NANOENGINEERING ${ }^{\text {TM }}$ (Table 1).

Table1: Sample of Nanomedicines ready for distribution to partners.

\begin{tabular}{|c|c|c|}
\hline Cyclosporine & Natamycin & Tropicamide \\
\hline Dexamethasone & & \\
\hline Difluoro- & & \\
\hline prednisolone & & \\
\hline Fluorometholone & & \\
\hline & Statin & \\
\hline
\end{tabular}

\section{The Industry and Life Cycle Management}

In addition to the benefit of a more effective drug delivery system, and by extension allowing for decreased dosages and the reduction or possible elimination of side effects, the cash cow for this company lies in its ability to potentially extend patent protection for the horde of multibillion dollar blockbuster drugs facing the dreaded patent cliff. During 2012-2018 over US \$290 billion of sales are at risk from patent expirations. In fact, in 2013 alone patents will expire on drugs with yearly sales of US $\$ 29$ billion. Generics are expected to grab $70 \%$ of those sales.
In the past 10 years, a huge amount of money has been thrown at acquisitions and the restructuring of research and development (R\&D), in an attempt to replace the revenues that are under threat from patent expiries. Over the same time, Evaluate Pharma estimated that $\$ 1.1$ trillion has been invested in $R \& D$ in a bid to revitalize pipelines.

In 2010, the pharmaceutical industry had sales of $\$ 860$ billion worldwide, up 3\% from 2009. Just 133 blockbuster drugs accounted for $\$ 295$ billion of those sales about $34 \%$ of the market. Of those blockbusters, 13 are set to lose patent protection through 2017.

Meda is position itself only to exploit the drugs that has problems of their optimal uses with respect of its bioavailability, optimal dose and toxicity. The unique technology discovered by Meda Biotech does not have any competition. Discovery does only resolved the bioavailability problem but added synergistic and potentiating effects to treatment.

Our technology will allow drug companies to modify the delivery, pharmacokinetics and dosage that, in addition to significantly reducing or eliminating side effects, it would be patentable. New patents can run for 20 years. The global ophthalmic drugs market is growing rapidly and is expected to witness healthy growth in the next five years. Some of the key driving factors for the market are increasing prevalence of eye disorders such as glaucoma, dry eye diseases and retinal diseases. Changing lifestyle, improved medical infrastructure, technological changes, increase in healthcare spending and aging population are also supporting the growth of the global ophthalmic drugs market.

However, various restraints, such as less awareness about ophthalmic disorders and absence of health insurance among the elderly population in developing nations such as India and China, are hampering growth of the global ophthalmic drugs market. Treatment based drugs in global ophthalmic drugs market 


\section{Global Journal of Nanomedicine}

comprises treatment of major eye disorders such as glaucoma, dry eye drugs, retinal diseases and ocular inflammatory diseases

Our technology has a potential to rejuvenate ageing pharmaceutical assets to counteract generic threats and preserve market share and income streams it could become one of the more successful specialty pharmaceutical companies in memory. Pharmaceutical companies desperately need to protect their revenue streams especially towards the end of their patent life as this is when their products are most profitable. For that reason, upfront and milestone payments should be significant and commensurate to the perceived value brought to the project by adopting HYBRID-NANOENGINEERING ${ }^{\mathrm{TM}}$ technology.

In addition to milestone payments, royalties would continue for the life of the newly patented product. For drug delivery companies, royalty rates are generally accepted to be in the $7 \%$ to $12 \%$ range. Meda is providing much more than just delivery system. Our Strong patent estate and low development costs for new formulations appears to provide for the least expensive and expedient method for preserving patents and revenue. In addition to milestone payments, royalties would continue for the life of the newly patented product. For drug delivery companies, royalty rates are generally accepted to be in the $7 \%$ to $12 \%$ range depending on the time and expense of adopting the extended release mechanism. Crown's Strong patent estate and low development costs for new formulations appears to provide for the least expensive and expedient method for preserving patents and revenue streams.

As companies bulked up to take on copies of the world's bestselling drugs, a wave of mergers has swept the industry. Many credit Actavis (\$ ACT) CEO Paul Bisaro with starting that trend; then the Watson CEO, his 2012 takeover of Actavis sent a clear message of "go big or go home" reverberating throughout the generics business. Another message will come soon "make the patent expired better or go home. There are new technologies to make a big difference in old drug's efficacy and safety, you can say biobetter or chemobetter. Actives haven't stopped scouting for deals, and many of its peers have followed suit.

Companies are joining forces to take on new markets, too. Like branded drug makers, generics companies are looking toward emerging markets now that some of the biggest blockbusters have already fallen to generic competition and Western markets are stagnating. Many generics makers have teamed up with or bought local companies that can help with manufacturing, marketing and distribution. Big Pharma companies add their names--and lend their prestige--to domestically made products to differentiate them from the masses of competition. And joining forces with the locals can sometimes be a requirement. To sell one of 70-plus essential drugs in South Africa, companies have to make those drugs in South Africa. Russia requires foreign drug makers to partner with local companies and share technology to get in on the action in that market.

\section{Generic Business -A brief overview}

The repurposing of previously approved molecules for other indications into products reformulated and optimized for ophthalmic delivery has the advantage of leveraging longterm relevant safety data in humans, offering a regulatory advantage with the US FDA approval process. If differentiated, IP protection is sought after, to gain maximum product lifecycle extension for these products. In lock-step with these products is the generic ophthalmic products industry, offering high quality, pharmaceutically compliant products at an affordable cost. Thus, the ophthalmic products industry continues to seek a fine balance between innovation to meet both business and clinical needs and a relatively short regulatory timeline.

We are looking for collaboration either from established companies or new investors to join us to take advantage of this new discovery in the field of Nanotechnology for Nanomedicines (Figure $1 \& 2$ ).

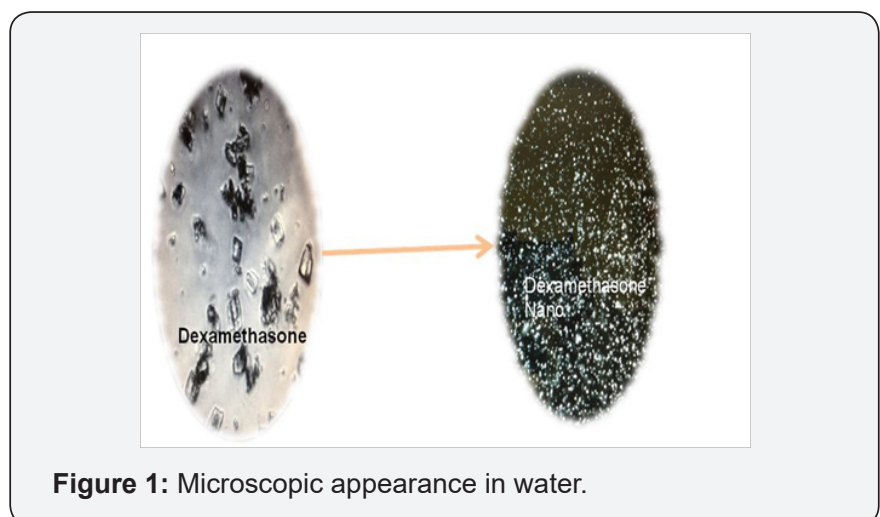

Figure 1: Microscopic appearance in water.

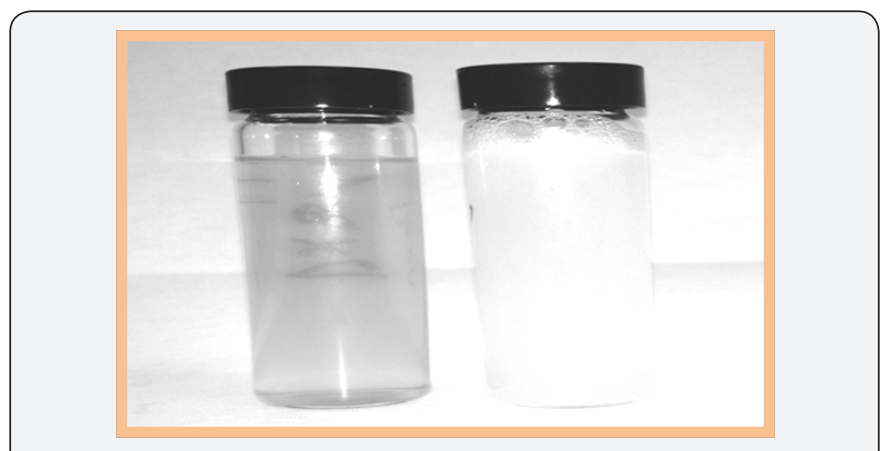

Figure 2: Comparative Water solubility.

\section{Example 1: Dexamethasone}

a. Problems: Only 1-5\% of the applied drug penetrates the cornea and goes into intraocular tissues because of its poor bioavailability.

b. About $45 \%$ new discovered drugs have solubility problem and need our technology. A genuine need for improvement. Technical Data for some ophthalmic formulation using our HYBRID-NANOENGINEERING ${ }^{\text {TM }}$ technology. 


\section{Example 2: Cyclosporine}

- $\quad$ Cyclosporine A (CsA) has been widely used as a potent immunosuppressive agent in spite of its low oral bioavailability and formulation problems.

- A genuine need for nano formulation for better performance.

- The United States cyclosporine market accounts for $\$ 480$ million in sales annually.

\section{Problem}

Cyclosporine A (CyA) is a poorly water-soluble, cyclic undecapeptide having immunosuppressive properties. It is used to prevent rejection of transplanted organs such as kidney, liver and bone marrow, and in the treatment of selected autoimmune disorders such as uveitis, rheumatoid arthritis and early treatment of type I diabetes. Due to its relatively high molecular weight, lipophilicity and poor aqueous solubility, oral absorption of CyA is low and highly variable. As such, the current formulation of CyA for oral administration (Neoral) is one which spontaneously forms a micro emulsion in an aqueous environment. For the injectible formulation (Sandimmune), Cremophor EL is used for solubilising CyA which has the associated side effects of nephrotoxicity, anaphylactic hypersensitivity reactions, hyperlipidaemia, abnormal lipoprotein patterns, aggregation of erythrocytes and peripheral neuropathy (Figure $3 \& 4$ ).
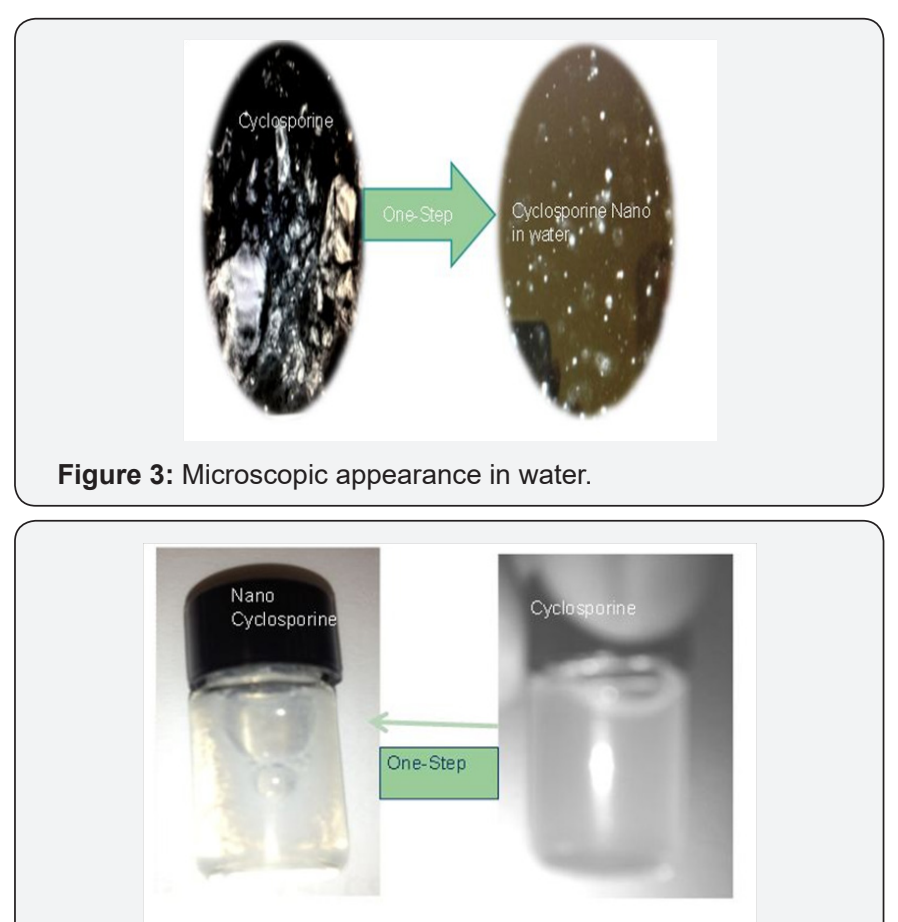

Figure 4: Comparative solubility in water.

\section{New Hybrid Cyclosporine}

- Water soluble

- Hybrid, double edge formulation

- $\quad$ Less toxic

- High potency

- Low manufacturing and administration cost at clinic

- $\quad$ No change in integrity of the molecules

- $\quad$ Patent filed for new invention for hybrid.

- $\quad$ No castor oil, no alcohol, no detergent, no protein, no chemistry change on top of that it is more potent, less toxic and less manufacturing cost.

- $\quad$ No complex conjugation steps

- Low manufacturing cost and simple to administer at dr's. Site

\section{Hybrid-Nanoengineering $^{\mathrm{Tm}}$}

A new discovery for tough molecules to solve their solubility problem using Nanotechnology that is Go-Green (Figure 5)

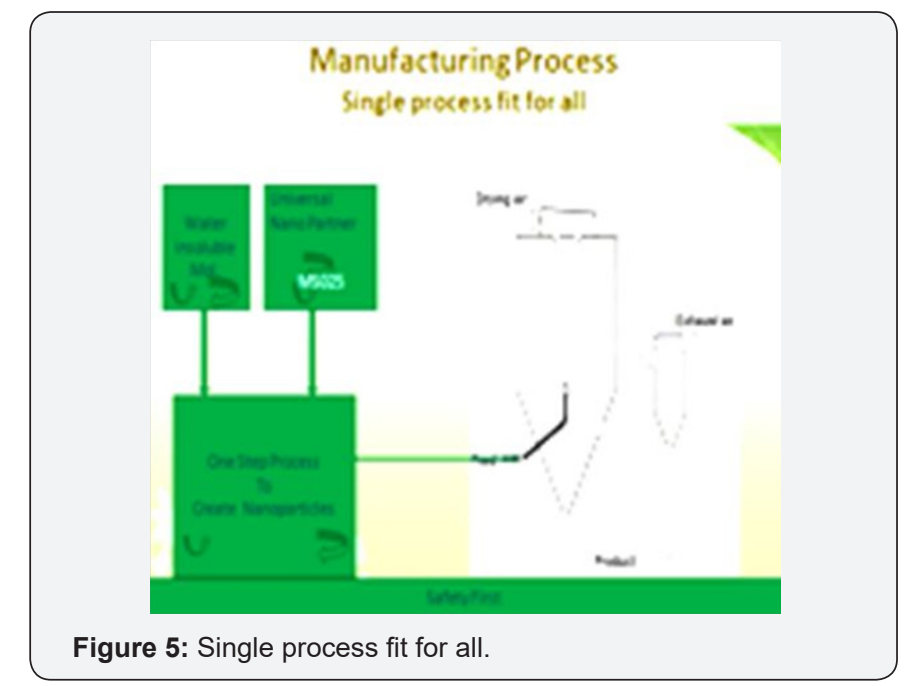

a. Just one step is involved for manufacturing of nano particles.

b. Only one discovered reagent is required in technology.

c. GRAS approved reagents involved in process.

d. No special machinery is required for manufacturing.

e. Most economic technology till to date.

f. Multiple uses provide synergistic effects to active molecules. 
This work is licensed under Creative Commons Attribution 4.0 License

DOI: 10.19080/GJN.2017.02.555594
Your next submission with JuniperPublishers will reach you the below assets

- Quality Editorial service

- Swift Peer Review

- Reprints availability

- E-prints Service

- Manuscript Podcast for convenient understanding

- Global attainment for your research

- Manuscript accessibility in different formats

( Pdf, E-pub, Full Text, Audio)

- Unceasing customer service

Track the below URL for one-step submission https://juniperpublishers.com/submit-manuscript.php 